\title{
Desorption of chromium (VI) and lead (II) ions and regeneration of the exhausted adsorbent
}

\author{
Jonas Bayuo ${ }^{1,2}$ - Moses Abdullai Abukari ${ }^{2} \cdot$ Kenneth Bayetimani Pelig-Ba ${ }^{1}$
}

Received: 2 May 2020 / Accepted: 11 June 2020 / Published online: 25 June 2020

(c) The Author(s) 2020

\begin{abstract}
The desorption characteristics of previously adsorbed hexavalent chromium [Cr(VI)] and divalent lead $[\mathrm{Pb}(\mathrm{II})]$ ions on groundnut husk were tested by various desorption eluents such as tap water, de-ionized water, $\mathrm{NaOH}, \mathrm{HCl}$ and $\mathrm{H}_{2} \mathrm{SO}_{4}$. Among them, $\mathrm{HCl}$ and $\mathrm{H}_{2} \mathrm{SO}_{4}$ were chosen as the best desorbing agents for $\mathrm{Cr}(\mathrm{VI})$ and $\mathrm{Pb}(\mathrm{II})$ ions, respectively, due to their high desorption efficiency. The desorption efficiency of $\mathrm{HCl}$ and $\mathrm{H}_{2} \mathrm{SO}_{4}$ for $\mathrm{Cr}(\mathrm{VI})$ and $\mathrm{Pb}$ (II) ions was about $76.1 \%$ and $82.1 \%$, respectively, at a concentration of $0.1 \mathrm{M}$ for both elution agents. The exhausted groundnut husk was regenerated up to five cycles, and the removal efficiency of $\mathrm{Cr}(\mathrm{VI})$ and $\mathrm{Pb}$ (II) ions on the recycled groundnut husk could be maintained at $53.5 \%$ and $54.6 \%$, respectively, in the third cycle. The successive regeneration cycles resulted in the reduction of the desorption efficiency by $20.0 \%$ and $26.7 \%$ for $\mathrm{Cr}(\mathrm{VI})$ and $\mathrm{Pb}$ (II) ions, respectively, after the third cycle. The results show that groundnut husk could be recycled when used to remove $\mathrm{Cr}(\mathrm{VI})$ and $\mathrm{Pb}(\mathrm{II})$ ions from $\mathrm{Cr}(\mathrm{VI})$ and $\mathrm{Pb}(\mathrm{II})$-polluted water and wastewaters.
\end{abstract}

Keywords Adsorbent $\cdot$ Biosorption $\cdot$ Desorption $\cdot$ Regeneration $\cdot$ Heavy metals

\section{Introduction}

Environmentalists and government agencies both locally and globally are worried about the health risks accompanying heavy metals poisoning in living organisms and underscore the need for continuous research intending to combat the problems of environmental pollution by these toxic metals. Industrial growth has led to a significant increase in naturally occurring metals' levels as experienced currently (Bayuo et al. 2019a, b; Mireles et al. 2012). Contamination of natural environment by heavy metals has to turn out to be a major issue worldwide, and Ghana is no exception because of their toxicity and potential health risks posed to biological organisms when consumed beyond the acceptable limits (Prabha and Udayashankara 2014).

Jonas Bayuo

jonas87bayuo@yahoo.com

1 Department of Applied Chemistry and Biochemistry, C.K. Tedam University of Technology and Applied Sciences, Postal Box 24, Navrongo, Upper East Region, Ghana

2 Department of Science and Mathematics Education, C.K. Tedam University of Technology and Applied Sciences, Postal Box 24, Navrongo, Upper East Region, Ghana
It is a fact that agriculture and mining remain the major key contributors to chemical pollution in Ghana. Vegetable and crop farming in Ghanaian agriculture is prone to either misuse or overuse of fertilizers, pesticides and fungicides. Diseases and pests pose big challenges and problems in crop and vegetable production that usually compelled farmers to use chemical pesticides even if they have no technical know-how in application procedures. Furthermore, the rapid population growth along water sources in Ghana has necessitated proper conservation and efficient utilization of freshwater bodies due to heavy metals and other toxic chemicals. This is because there has been accelerated deterioration of water quality within water bodies due to increased domestic, municipal, industrial, mining and agricultural activities (Dadzie 2012). The sudden increase in illegal small-scale gold mining popularly called "galamsey" in the local communities, especially in Ghana, has led to concerns about the level of environmental pollution coming from these mining activities (Kpan et al. 2014). The emission of heavy metals into the environment from mining operations (Abas et al. 2014; Nriagu 1988) will pollute the surface and underground water sources as well as agricultural soil. When agricultural soils are polluted, these metals are taken up by plants and consequently accumulate in their tissues (Trüby 2003). 
Humans and animals that eat and graze on such contaminated plants and drink from polluted waters, as well as aquatic organisms that breed in heavy metal polluted waters, accumulate such toxic metals in their tissues and milk if lactating (Horsfall and Spiff 1999). These accumulated heavy metals tend to cause various diseases and disorders in living organisms (Teker and Imamoglu 2005).

Chromium (VI) and lead (II) are being classified by the United States Environmental Protection Agency (USEPA) as potentially hazardous to most living species (Babu et al. 1987). Chromium (VI) is well known due to its healthrelated issues in humans including carcinogenic and mutagenic risks (Bayuo et al. 2019a, b; Igwe 2007), while neurological disorders in humans, particularly children and in a fetus, are due to the chronic consequences of lead (II) (Bayuo et al. 2019a, b; Lalhruaitluanga et al. 2010).

Therefore, it is necessary to remove metal-contaminated water and wastewaters before its discharge to the environment. However, the disposal of the used adsorbent is again an environmental problem and constitutes a disposal problem. Hence, there is also the need to desorbed toxic ions on the surface of the used adsorbent to regenerate it for further use or to ensure safe disposal. Recently, the interest in desorption and re-utilization of adsorbents in metal recovery processes from water and wastewaters has deepened (Kwon and Jeon 2012). Desorption of ions can be performed to restore the adsorbent for further use (Bhuvaneshwari et al. 2012; Grover et al. 2012). After desorption, the metals can be recovered by extraction from the liquid phase so that the naturally low-cost adsorbents could be preserved. Biosorbent regeneration is the supreme fundamental method in assessing its commercial applicability, especially, in both batch and continuous processes, when expensive and selective sorbents are used (Lim and Aris 2014). During desorption procedures, ions accumulated on the biomaterial can be removed easily under appropriate operating procedures, and the adsorbent recycled several times to decrease material cost (Kahraman et al. 2008; Pan et al. 2009). Desorption can be performed by proton exchange using acids, chelating agents or exchange with other ions (Kwon and Jeon 2012). The choice of desorbing agents depends on the kind of adsorbent used and the metals adsorbed.

The removal of $\mathrm{Cr}(\mathrm{VI})$ and $\mathrm{Pb}(\mathrm{II})$ ions from wastewater has been widely studied using groundnut husk, and these studies have already shown that $\mathrm{Cr}(\mathrm{VI})$ and $\mathrm{Pb}(\mathrm{II})$ ions could be adsorbed by groundnut husk, which has economic merits compared to other adsorbents (Bayuo et al. 2019a, b). Unfortunately, however, there is little study on the recovery of the $\mathrm{Cr}(\mathrm{VI})$ and $\mathrm{Pb}(\mathrm{II})$ ions-laden adsorbents and regeneration of these adsorbents. The present study seeks to provide a greater understanding of the dynamic characteristics for desorption and regeneration of $\mathrm{Cr}(\mathrm{VI})$ and $\mathrm{Pb}(\mathrm{II})$ ions adsorbed onto groundnut husk using different desorbing agents.

\section{Materials and methods}

\section{Adsorbent material and characterization}

Raw groundnut husk powder was the adsorbent of interest in this study. The physicochemical composition of the groundnut husk was determined in our previous studies using Fourier transform infrared spectrometer (FT-IR) and scanning electron microscopy (SEM) (Bayuo et al. 2019a, b).

\section{Adsorbate solutions}

The chemicals and reagents employed for the experiments were of analytical grade and were supplied by the Technician of Applied Chemistry and Biochemistry Laboratory, C.K. Tedam University of Technology and Applied Sciences formerly, known as University for Development Studies, Navrongo Campus. Seperate stock solutions (1000 mg/L) of $\mathrm{Cr}(\mathrm{VI})$ and $\mathrm{Pb}$ (II) were prepared by dissolving the appropriate amount of salts, $1.599 \mathrm{~g}$ of lead nitrate $\left[\mathrm{Pb}\left(\mathrm{NO}_{3}\right)_{2}\right]$ and $2.829 \mathrm{~g}$ of potassium dichromate $\left(\mathrm{K}_{2} \mathrm{Cr}_{2} \mathrm{O}_{7}\right)$ in de-ionized water, and diluted to the $1000-\mathrm{mL}$ mark with de-ionized water. Working solutions were prepared by diluting stock solutions with deionized water.

\section{Desorption and regeneration studies}

To carry out the desorption and regeneration studies, $2.0 \mathrm{~g} / \mathrm{L}$ of the adsorbent of $0.063 \mathrm{~mm}$ particle size was introduced into Erlenmeyer flasks containing $25 \mathrm{mg} / \mathrm{L}$ of each metal ion $[\mathrm{Cr}(\mathrm{VI})$ and $\mathrm{Pb}(\mathrm{II})]$ in $100 \mathrm{~mL}$. After equilibration for $60 \mathrm{~min}$ under room temperature, the adsorbent was recovered and the adsorption capacity determined. Residual metal ions on the used adsorbent surface were detached through washing for three consecutive times using distilled water and then dried in an oven at $105^{\circ} \mathrm{C}$ to constant mass. Five different desorption agents, tap water, de-ionized water, $0.1 \mathrm{M} \mathrm{NaOH}, 0.1 \mathrm{M} \mathrm{HCl}$ and $0.1 \mathrm{M} \mathrm{H}_{2} \mathrm{SO}_{4}$, were used to desorbed the metal ions from the adsorbent. Exactly, $40 \mathrm{~mL}$ of the desorption agents was kept in $100 \mathrm{~mL}$ Erlenmeyer flasks with the recovered adsorbent and agitated for 60 min with continuous agitation at a $120 \mathrm{rpm}$ at a temperature of $30 \pm 0.5^{\circ} \mathrm{C}$. The adsorbate-adsorbent mixtures were filtered after equilibration using Whatman 42 filter paper. The concentration of the $\mathrm{Cr}(\mathrm{VI})$ and $\mathrm{Pb}$ (II) ions in the filtrate was determined spectrophotometrically (UV-vis spectrophotometer) by diphenyl-carbazide (Bayuo et al. 2019a, b; Mahajan and Sud 2012) and dithizone (Bayuo et al. 2018; APHA 1989) methods, respectively.

Percentage desorption was calculated using the equation below (Katsou et al. 2011): 
Desorption efficiency $(\%)=\frac{C_{\mathrm{de}}}{C_{\mathrm{ad}}} \times 100$

where $C_{\text {ad }}$ denotes the amount of metal ions adsorbed and $C_{\mathrm{de}}$ is the concentration of metal ions desorbed. The recovered adsorbent was dried at $105^{\circ} \mathrm{C}$ to constant mass, and so the regenerated adsorbent was used in adsorption-desorption cycles to determine the reusability of the groundnut husk. The reusability of the groundnut husk was conducted in five successive adsorption-desorption cycles.

The amount of each metal desorbed from the groundnut husk into the solution per unit mass of adsorbent, $Q_{d}(\mathrm{mg} / \mathrm{g})$ at equilibrium is calculated by (Katsou et al. 2011):

$Q_{d}=\frac{C_{\mathrm{de}}}{m} \times V$

where $C_{\mathrm{de}}(\mathrm{mg} /)$ is the liquid phase metal concentration detected in the desorbing solution at equilibrium conditions, $m$ is mass of adsorbent and $V(\mathrm{~L})$ is the volume of the desorbing solution.

\section{Results and discussion}

\section{Desorption of $\mathrm{Cr}(\mathrm{VI})$ and $\mathrm{Pb}(\mathrm{II})$ ions loaded on the groundnut husk}

Desorption studies were conducted to select the optimum desorbing solution to be employed in successive regeneration cycles.

The desorption experiments shown in Fig. 1 indicate that the $\mathrm{HCl}$ and $\mathrm{H}_{2} \mathrm{SO}_{4}$ recovered about $76.1 \%$ and $56.0 \%$ of $\mathrm{Cr}(\mathrm{VI})$ adsorbed on the adsorbent surface, respectively. Conversely, in Fig. 2, $\mathrm{H}_{2} \mathrm{SO}_{4}$ and $\mathrm{HCl}$ were able to recover $82.1 \%$ and $74.2 \%$ of the $\mathrm{Pb}$ (II) adsorbed on the adsorbent surface, respectively. Tap water, distilled water and $\mathrm{NaOH}$ showed low desorption percentages of $8.4 \%, 24.7 \%$ and $34.4 \%$ for

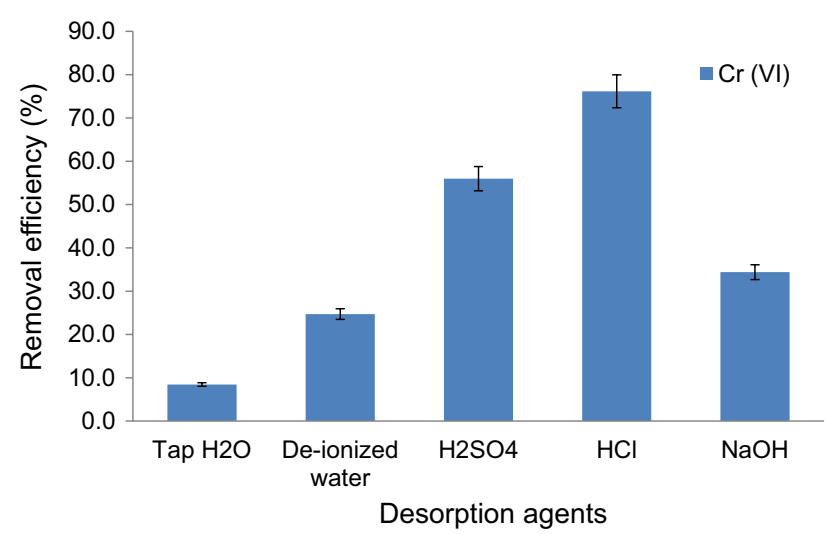

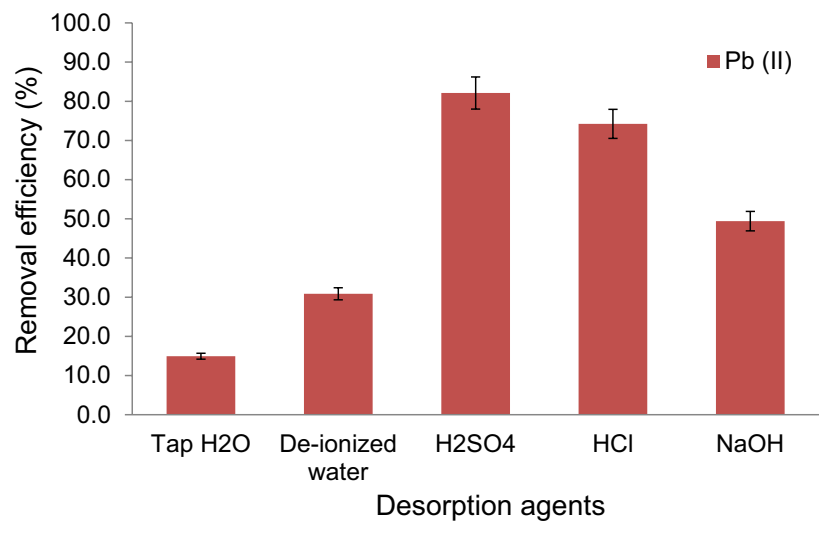

Fig. 2 Desorption of $\mathrm{Pb}$ (II) ions adsorbed on groundnut husk

$\mathrm{Cr}(\mathrm{VI})$ ion and $14.9 \%, 30.9 \%$ and $49.4 \%$ for $\mathrm{Pb}(\mathrm{II})$ ion, respectively. The study indicated that $\mathrm{Cr}(\mathrm{VI})$ and $\mathrm{Pb}$ (II) ions accumulated onto the groundnut husk could be desorbed and maximum percentage recovery of $\mathrm{Cr}(\mathrm{VI})$ and $\mathrm{Pb}(\mathrm{II})$ ions was $76.1 \%$ and $82.1 \%$ with $0.1 \mathrm{M} \mathrm{HCl}$ and $0.1 \mathrm{M} \mathrm{H}_{2} \mathrm{SO}_{4}$, respectively. Therefore, $0.1 \mathrm{M} \mathrm{HCl}$ and $0.1 \mathrm{M} \mathrm{H}_{2} \mathrm{SO}_{4}$ solutions were selected, respectively, as desorption reagents for removing $\mathrm{Cr}(\mathrm{VI})$ and $\mathrm{Pb}(\mathrm{II})$ ions from the groundnut husk surface.

The resultant desorption phenomenon observed in Figs. 1 and 2 for $\mathrm{Cr}(\mathrm{VI})$ and $\mathrm{Pb}$ (II) ions using $\mathrm{HCl}$ and $\mathrm{H}_{2} \mathrm{SO}_{4}$ as desorption agents, respectively, might be attributed to ion exchange type interaction rather than chemical sorption (Rotimi and Okeoghene 2014). Desorption is useful for the recovery and separation of metal ions in addition to the regeneration of the exhausted bisorbent (Rais et al. 2012, 2013). The hydroxyl and carboxylic groups in the groundnut husk made it amenable to easy desorption and regeneration with the acid solutions (Bayuo et al. 2019a, b; Johnson et al. 2008; Mireles et al. 2012).

The results of this study contradict the finding of Bhuvaneshwari et al. (2012) who studied on regeneration of chitosan after $\mathrm{Cr}(\mathrm{VI})$ sorption. In their study, $0.1 \mathrm{M} \mathrm{H}_{2} \mathrm{SO}_{4}$ was the best desorption agent and maximum desorption efficiency of $\mathrm{Cr}(\mathrm{VI})$ was found to be $88 \%$ under the following optimum conditions: agitation speed of $120 \mathrm{rpm}$, a contact time of $60 \mathrm{~min}$ and temperature of $40^{\circ} \mathrm{C}$. Furthermore, Wan et al. (2010) investigated the desorption of $\mathrm{Pb}$ (II) and $\mathrm{Cu}$ (II) ions from chitosan-coated sand in a batch system using tap water and diluted $\mathrm{HCl}$ solutions. The results signified that more metal ions could be recovered by the $\mathrm{HCl}$ with desorption efficiency of $97.91 \%$ and $99.22 \%$ for $\mathrm{Pb}$ (II) and $\mathrm{Cu}(\mathrm{II})$, respectively.

Fig. 1 Desorption of $\mathrm{Cr}(\mathrm{VI})$ ions adsorbed on groundnut husk 


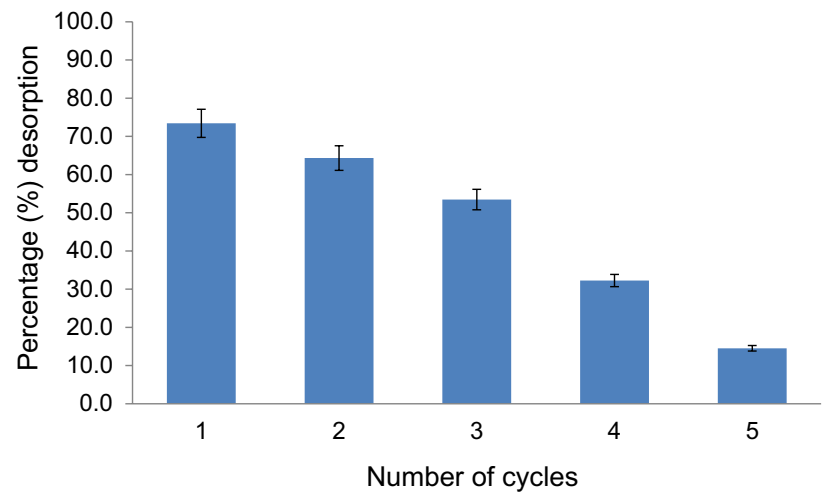

Fig. 3 Adsorption-desorption of $\mathrm{Cr}(\mathrm{VI})$ ions and reusability of adsorbent using $\mathrm{HCl}$ as desorbing agent

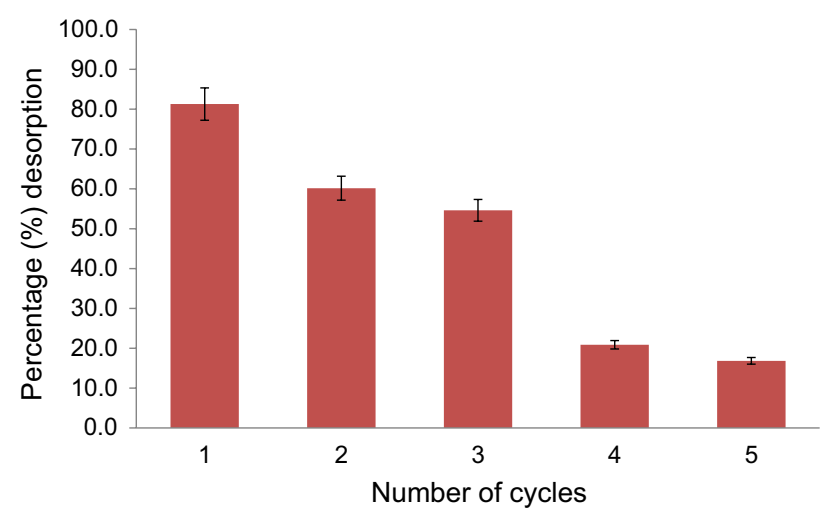

Fig. 4 Adsorption-desorption of $\mathrm{Pb}$ (II) ions and reusability of adsorbent using $\mathrm{H}_{2} \mathrm{SO}_{4}$ as desorbing agent

\section{Regeneration and reusability of the groundnut husk}

Several adsorption-desorption cycles were conducted for $\mathrm{Cr}(\mathrm{VI})$ and $\mathrm{Pb}(\mathrm{II})$ ions to determine the adsorption-desorption potential of the groundnut husk, once it had been regenerated several times. The reusability of the used adsorbent was investigated by performing five successive adsorption-desorption cycles of $\mathrm{Cr}(\mathrm{VI})$ and $\mathrm{Pb}$ (II) ions on the adsorbent using $0.1 \mathrm{M} \mathrm{HCl}$ and $0.1 \mathrm{M} \mathrm{H}_{2} \mathrm{SO}_{4}$ as respective desorption eluents. There was a gradual decrease in $\mathrm{Cr}(\mathrm{VI})$ and $\mathrm{Pb}(\mathrm{II})$ removal efficiencies with an increasing number of cycles as shown in Figs. 3 and 4, respectively. It was observed that cycles 1, 2 and 3 showed good retrieval of both metal ions accumulated on the adsorbent surface. For $\mathrm{Cr}(\mathrm{VI})$, the removal efficiencies of cycles 1,2 and 3 were found to be $73.4 \%, 64.3 \%$ and $53.5 \%$, respectively, as presented in Fig. 3. While in Fig. 4, the removal efficiencies of $\mathrm{Pb}(\mathrm{II})$ for cycles 1,2 and 3 were found to be $81.3 \%$, $60.2 \%$ and $54.6 \%$, respectively. Hence, after the sequence of three cycles, the $\mathrm{Cr}(\mathrm{VI})$ and $\mathrm{Pb}(\mathrm{II})$ uptake capacity on the adsorbent was reduced from 73.4 to $53.5 \%$ and 81.3 to
$54.6 \%$, respectively. The regeneration experiments presented in Figs. 3 and 4 showed that the groundnut husk could be reused repeatedly in the adsorption and recovery of $\mathrm{Cr}(\mathrm{VI})$ and $\mathrm{Pb}$ (II) ions without significantly losing its adsorption properties.

Generally, regeneration is a key factor in improving the economy of the adsorption process and accessing the potential of the adsorbent for commercial applications. From the regeneration studies presented in Figs. 3 and 4, $\mathrm{Cr}(\mathrm{VI})$ and $\mathrm{Pb}(\mathrm{II})$ ions uptake capacity on the groundnut husk was reduced after a sequence of three cycles. After this, no significant desorption was observed which indicated that a considerable part of the metal ions adsorbed was due to irreversible sorption. Hence, chemisorption has an important influence on metal ions removal (Kulkarni and Kaware 2015). The loss in the uptake capacity of the groundnut husk for $\mathrm{Cr}(\mathrm{VI})$ and $\mathrm{Pb}(\mathrm{II})$ uptake during the first three cycles was found to be $19.96 \%$ and $26.65 \%$, respectively. This could be attributed to the ignorable adsorbent load lost for the period of the adsorption-desorption cycles. The groundnut husk could be reutilized repeatedly in $\mathrm{Cr}(\mathrm{VI})$ and $\mathrm{Pb}$ (II) adsorption processes since the $\mathrm{Cr}(\mathrm{VI})$ and $\mathrm{Pb}(\mathrm{II})$ ions could be desorbed and adsorbent regenerated up to three cycles by $0.1 \mathrm{M} \mathrm{HCl}$ and $0.1 \mathrm{M} \mathrm{H}_{2} \mathrm{SO}_{4}$, respectively. This means that the adsorbent offered an economic benefit to be recycled repeatedly in $\mathrm{Cr}(\mathrm{VI})$ and $\mathrm{Pb}(\mathrm{II})$ adsorption process. It has been found that if the used adsorbent could be regenerated and used again at the end of the first cycle, then the adsorbent is said to be economical and could be used commercially (Rais et al. 2012).

The findings of this study could be compared to the findings of other studies on desorption and regeneration of exhausted biosorbents.

Gupta and Rastogi (2008) investigated sorption and desorption studies of chromium (VI) from the nonviable cyanobacterium Nostoc muscorum biomass. Sorption-desorption of chromium into inorganic solutions and distilled water were observed and the study indicated that the biosorbent could be regenerated using $0.1 \mathrm{M} \mathrm{HNO}_{3}$ and EDTA with up to $80 \%$ recovery. The biosorbent was reused in five biosorption-desorption cycles without a significant loss in the biosorption capacity.

Katsou et al. (2011) studied the regeneration of natural zeolite polluted by lead (II) and zinc (II) in wastewater treatment systems. Several desorbing solutions such as $\mathrm{HNO}_{3}$, $\mathrm{NaCl}, \mathrm{KCl}$ and $\mathrm{NH}_{4} \mathrm{Cl}$ were examined for the removal of $\mathrm{Pb}$ (II) and $\mathrm{Zn}$ (II) from zeolite, and the highest desorption efficiency was obtained for $3 \mathrm{M} \mathrm{KCl}$ and $1 \mathrm{M} \mathrm{KCl}$, respectively. $\mathrm{KCl}$ was the most effective solution for the desorption process exhibiting very high desorption efficiencies (>98.5\%) for both metals.

Kwon and Jeon (2012) conducted a study on the desorption and regeneration characteristics for previously 
adsorbed indium ions to phosphorylated sawdust. Various chemical reagents such as $\mathrm{HCl}, \mathrm{HNO}_{3}, \mathrm{NaCl}$, ethylenediaminetetraacetic acid and nitrilotriacetic acid were tested on the desorption characteristics of indium ions adsorbed on phosphorylated sawdust. Among them, $\mathrm{HCl}$ was chosen as the best desorbing agent with a desorption efficiency of $97 \%$ at a concentration of $0.5 \mathrm{M}$.

A study was conducted by Hossain et al. (2012) on the adsorption and desorption of copper (II) ions onto garden grass. In their study, the desorption of adsorbed $\mathrm{Cu}$ (II) from exhausted garden grass was explored using eight types of desorption eluents including tape water, Milli-Q water, distilled water, $0.1 \mathrm{~N} \mathrm{H}_{2} \mathrm{SO}_{4}, 0.1 \mathrm{~N} \mathrm{HCl}, 0.1 \mathrm{~N} \mathrm{HNO}_{3}, 0.1 \mathrm{~N}$ $\mathrm{NaOH}$ and $0.1 \mathrm{~N} \mathrm{CH}_{3} \mathrm{COOH}$. It was found that $0.1 \mathrm{~N} \mathrm{H}_{2} \mathrm{SO}_{4}$ was a suitable eluent, which could be used up to five cycles of adsorption-desorption.

In most studies, it is found that the desorption of metal ions in acidic media appeared to be rapid and higher than in basic and neutral media (Samadder et al. 2014).

\section{Conclusion}

Batch adsorption-desorption studies were performed for the removal of chromium (VI) and lead (II) ions from aqueous solutions using groundnut husk. The selected adsorbent is viewed as a useful material while considering the economic aspects of wastewater treatment. The study indicated the suitability of the groundnut husk to be regenerated by removing chromium (VI) and lead (II) ions adsorbed on the adsorbent using $\mathrm{HCl}$ and $\mathrm{H}_{2} \mathrm{SO}_{4}$, respectively, as their best desorption eluents. The results showed that for most desorbing solutions lead (II) was more effectively desorbed than chromium (VI) with desorption efficiencies of $82.1 \%$ and $76.1 \%$, respectively. Furthermore, the exhausted adsorbent was regenerated up to three cycles indicating its suitability to be utilized repeatedly in $\mathrm{Cr}(\mathrm{VI})$ and $\mathrm{Pb}$ (II) ions mitigation processes.

\section{Compliance with ethical standards}

Conflict of interest The authors declare that there is no conflict of interest regarding the publication of this paper.

Open Access This article is licensed under a Creative Commons Attribution 4.0 International License, which permits use, sharing, adaptation, distribution and reproduction in any medium or format, as long as you give appropriate credit to the original author(s) and the source, provide a link to the Creative Commons licence, and indicate if changes were made. The images or other third party material in this article are included in the article's Creative Commons licence, unless indicated otherwise in a credit line to the material. If material is not included in the article's Creative Commons licence and your intended use is not permitted by statutory regulation or exceeds the permitted use, you will need to obtain permission directly from the copyright holder. To view a copy of this licence, visit http://creativecommons.org/licenses/by/4.0/.

\section{References}

Abas SNA, Ismail MHS, Kamal ML, Izhar S (2014) Adsorption process of heavy metals by low-cost adsorbent: a review. Res J Chem Environ 18(4):91-102. https://doi.org/10.5829/idosi .wasj.2013.28.11.1874

APHA (1989) APHA-standard method for the examination of water and wastewater. American Water Works Association and Water Pollution; ControlFederation, Washington, DC

Babu GN, Marco J, Bona-Gallo A, Gallo RV (1987) Steroid-independent endogenous opioid peptide suppression of pulsatile luteinizing hormone release between estrus and diestrus 1 in the rat estrous cycle. Brain Res 416(2):235-242. https://doi.org/10.1016/00068993(87)90902-4

Bayuo J, Pelig-Ba KB, Abukari MA (2018) Isotherm modeling of lead(II) adsorption from aqueous solution using groundnut shell as a low-cost adsorbent. IOSR J Appl Chem (IOSR-JAC) 11(11):1823. https://doi.org/10.9790/5736-1111011823

Bayuo J, Pelig-Ba KB, Abukari MA (2019a) Optimization of adsorption parameters for effective removal of lead (II) from aqueous solution. Phys Chem Indian J 14(1):1-25

Bayuo J, Pelig-Ba KB, Abukari MA (2019b) Adsorptive removal of chromium (VI) from aqueous solution unto groundnut shell. Appl Water Sci 9(4):1-11. https://doi.org/10.1007/s13201-019-0987-8

Bhuvaneshwari S, Sruthi D, Sivasubramanian V, Kanthimathy K (2012) Regeneration of chitosan after heavy metal sorption. J Sci Ind Res 71(4):266-269

Dadzie ES (2012) Assessment of heavy metal contamination of the Densu River, Weija from leachate. Kwame Nkrumah University of Science and Technology

Grover VA, Hu J, Engates KE, Shipley HJ (2012) Adsorption and desorption of bivalent metals to hematite nanoparticles. Environ Toxicol Chem 31(1):86-92. https://doi.org/10.1002/etc.712

Gupta VK, Rastogi A (2008) Sorption and desorption studies of chromium (VI) from nonviable cyanobacterium Nostoc muscorum biomass. J Hazard Mater 154(1-3):347-354

Horsfall MN, Spiff AI (1999) Speciation of heavy metals in intertidal sediments of the Okirika River system. Bull Chem Soc Ethiopia 13(1):1-9

Hossain MA, Ngo HH, Guo WS, Setiadi T (2012) Adsorption and desorption of copper (II) ions onto garden grass. Bioresour Technol 121:386-395. https://doi.org/10.1016/j.biortech.2012.06.119

Igwe JC (2007) Review of potentially low cost sorbents for heavy metal removal and recovery. Terr Aquat Environ Toxicol 1(2):60-69

Johnson TA, Jain N, Joshi HC, Prasad S (2008) Agricultural and agroprocessing wastes as low cost adsorbents for metal removal from wastewater: a review. J Sci Ind Res 67(9):647-658

Kahraman S, Dogan N, Erdemoglu S (2008) Use of various agricultural wastes for the removal of heavy metal ions. Int J Environ Pollut 34(1-4):275-284. https://doi.org/10.1504/IJEP.2008.020797

Katsou E, Malamis S, Tzanoudaki M, Haralambous KJ, Loizidou M (2011) Regeneration of natural zeolite polluted by lead and zinc in wastewater treatment systems. J Hazard Mater 189(3):773-786. https://doi.org/10.1016/j.jhazmat-.2010.12.061

Kpan JDA, Opoku BK, Gloria A (2014) Heavy metal pollution in soil and water in some selected towns in Dunkwa-on-Offin district in the central region of Ghana as a result of small scale gold mining. J Agric Chem Environ 03(02):40-47. https://doi.org/10.4236/ jacen.2014.32006

Kulkarni SJ, Kaware JP (2015) Desorption studies for low cost adsorbents. Int J Chem Stud 3(2):38-41

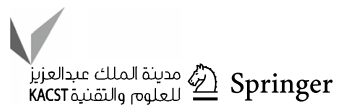


Kwon T, Jeon C (2012) Desorption and regeneration characteristics for previously adsorbed indium ions to phosphorylated sawdust. Environ Eng Res 17(2):65-67

Lalhruaitluanga H, Jayaram K, Prasad MNV, Kumar KK (2010) Lead (II) adsorption from aqueous solutions by raw and activated charcoals of Melocanna baccifera Roxburgh (bamboo) - a comparative study. J Hazard Mater 175:311-318

Lim AP, Aris AZ (2014) A review on economically adsorbents on heavy metals removal in water and wastewater. Rev Environ Sci Biotechnol 13(2):163-181. https://doi.org/10.1007/s1115 7-013-9330-2

Mahajan G, Sud D (2012) Modified agricultural waste biomass with enhanced responsive properties for metal-ion remediation: a green approach. Appl Water Sci 2(4):299-308. https://doi.org/10.1007/ s13201-012-0050-5

Mireles F, Davila JI, Pinedo JL, Reyes E, Speakman RJ, Glascock MD (2012) Assessing urban soil pollution in the cities of Zacatecas and Guadalupe, Mexico by instrumental neutron activation analysis. Microchem J 103:158-164. https://doi.org/10.1016/j. microc.2012.02.009

Nriagu JO (1988) A silent epidemic of environmental metal poisoning? Environ Pollut 50(1-2):139-161. https://doi.org/10.1016/02697491(88)90189-3

Pan B, Pan B, Zhang W, Lv L, Zhang Q, Zheng S (2009) Development of polymeric and polymer-based hybrid adsorbents for pollutants removal from waters. Chem Eng J 151(1-3):19-29. https://doi. org/10.1016/j.cej.2009.02.036

Prabha RT, Udayashankara TH (2014) Adsorption of copper metal ions from aqueous solution using rice husk and groundnut shell. Int J Sci Res 3(8):705-709
Rais A, Kumar R, Haseeb S (2012) Adsorption of $\mathrm{Cu}^{2+}$ from aqueous solution onto iron oxide coated eggshell powder: evaluation of equilibrium, isotherms, kinetics, and regeneration capacity. Arab J Chem 5(3):353-359. https://doi.org/10.1016/j.arabjc.2010.09.003

Rais A, Kumar R, Laskar M (2013) Adsorptive removal of $\mathrm{Pb}^{2+}$ form aqueous solution by macrocyclic calyx[4]naphthalene: kinetic, thermodynamic, and isotherm analysis. Environ Sci Pollut Res 20:219-226

Rotimi A, Okeoghene G (2014) Sorption and desorption studies on toxic metals from brewery effluent using eggshell as adsorbent. Adv Nat Sci 7(2):15-24. https://doi.org/10.3968/5394

Samadder SR, Lata S, Singh P (2014) Regeneration of adsorbents and recovery of heavy metals: a review. Int J Environ Sci Technol. https://doi.org/10.1007/-s13762-014-0714-9

Teker M, Imamoglu M (2005) Adsorption of copper and cadmium (II) ions by activated carbon from rice hulls. Turk J Chem 23:185-191

Trüby P (2003) Impact of heavy metals on forest trees from mining areas. Mining and the environment, sudbury, 2003

Wan MW, Kan CC, Rogel BD, Dalida MLP (2010) Adsorption of copper (II) and lead (II) ions from aqueous solution on chitosancoated sand. Carbohydr Polym 80(3):891-899. https://doi. org/10.1016/j.carbpol.2009.12.048

Publisher's Note Springer Nature remains neutral with regard to jurisdictional claims in published maps and institutional affiliations. 